\title{
Comparison of Measured and Calculated Carboxylation Rate, Electron Transfer Rate and Photosynthesis Rate Response to Different Light Intensity and Leaf Temperature in Semi-closed Greenhouse with Carbon Dioxide Fertilization for Tomato Cultivation
}

\author{
Eun-Young Choi ${ }^{1}$, Young-Ae Jeong ${ }^{2}$, Seung-Hyun An ${ }^{3}$, Dong-Cheol Jang ${ }^{4}$, Dae-Hyun Kim ${ }^{5}$, \\ Dong-Soo Lee ${ }^{6}$, Jin-Kyung Kwon ${ }^{7}$, and Young-Hoe Woo ${ }^{8}$ * \\ ${ }^{I}$ Professor, Department of Agricultural Science, Korea National Open University, Seoul 03087, Korea \\ ${ }^{2}$ Graduate Student, Department of Agriculture and Life Science, Korea National Open University, Seoul 03087, Korea \\ ${ }^{3}$ Undergraduate Student, Department of Agricultural Science, Korea National Open University, Seoul 03087, Korea \\ ${ }^{4}$ Postdoctoral Researcher, Department of Horticulture, College of Agriculture and Life Science, Kangwon National University, \\ Chuncheon 24341, Korea \\ ${ }^{5}$ Professor, Department of Biosystems Engineering, College of Agriculture and Life Science, Kangwon National University, \\ Chuncheon 24341, Korea \\ ${ }^{6}$ Postdoctoral Researcher, Department of Agricultural Engineering, Energy and Environmental Engineering Division, Jeonju \\ 54875, Korea \\ Researcher, Department of Agricultural Engineering, Energy and Environmental Engineering Division, Jeonju 54875, Korea \\ ${ }^{8}$ Professor, Department of Horticulture Environment System, Korea National College of Agriculture and Fisheries, Jeonju \\ 54874, Korea
}

\begin{abstract}
This study aimed to estimate the photosynthetic capacity of tomato plants grown in a semi-closed greenhouse using temperature response models of plant photosynthesis by calculating the ribulose 1,5-bisphosphate carboxylase/ oxygenase maximum carboxylation rate $\left(\mathrm{V}_{\mathrm{cmax}}\right)$, maximum electron transport rate $\left(\mathrm{J}_{\max }\right)$, thermal breakdown (hightemperature inhibition), and leaf respiration to predict the optimal conditions of the $\mathrm{CO}_{2}$-controlled greenhouse, for maximizing the photosynthetic rate. Gas exchange measurements for the $\mathrm{A}-\mathrm{C}_{\mathrm{i}}$ curve response to $\mathrm{CO}_{2}$ level with different light intensities $\left\{\right.$ PAR (Photosynthetically Active Radiation) $200 \mu \mathrm{mol} \cdot \mathrm{m}^{-2} \cdot \mathrm{s}^{-1}$ to $1500 \mu \mathrm{mol} \cdot \mathrm{m}^{-2} \cdot \mathrm{s}^{-1}$ \} and leaf temperatures $\left(20^{\circ} \mathrm{C}\right.$ to $\left.35^{\circ} \mathrm{C}\right)$ were conducted with a portable infrared gas analyzer system. Arrhenius function, net $\mathrm{CO}_{2}$ assimilation $\left(\mathrm{A}_{\mathrm{n}}\right)$, thermal breakdown, and daylight leaf respiration $\left(\mathrm{R}_{\mathrm{d}}\right)$ were also calculated using the modeling equation. Estimated $\mathrm{J}_{\max }, \mathrm{A}_{\mathrm{n}}$, Arrhenius function value, and thermal breakdown decreased in response to increased leaf temperature $\left(>30^{\circ} \mathrm{C}\right)$, and the optimum leaf temperature for the estimated $\mathrm{J}_{\max }$ was $30^{\circ} \mathrm{C}$. The $\mathrm{CO}_{2}$ saturation point of the fifth leaf from the apical region was reached at $600 \mathrm{ppm}$ for 200 and $400 \mu \mathrm{mol} \cdot \mathrm{m}^{-2} \cdot \mathrm{s}^{-1}$ of PAR, at $800 \mathrm{ppm}$ for 600 and $800 \mu \mathrm{mol} \cdot \mathrm{m}^{-2} \cdot \mathrm{s}^{-1}$ of $\mathrm{PAR}$, at $1000 \mathrm{ppm}$ for $1000 \mu \mathrm{mol}$ of PAR, and at $1500 \mathrm{ppm}$ for 1200 and $1500 \mu \mathrm{mol} \cdot \mathrm{m}^{-2} \cdot \mathrm{s}^{-1}$ of PAR levels. The results suggest that the optimal conditions of $\mathrm{CO}_{2}$ concentration can be determined, using the photosynthetic model equation, to improve the photosynthetic rates of fruit vegetables grown in greenhouses.
\end{abstract}

Additional key words : Arrhenius function, net $\mathrm{CO}_{2}$ assimilation, rubisco, saturation point, thermal breakdown

\section{Introduction}

The cultivation areas of vegetables were 171,429 ha for the open field and 54,443ha for the greenhouse. Most of the fruit vegetables $(85.6 \%)$ were grown in the greenhouse. Vegetable production in greenhouses has been continuously declining since reaching 3.13 million tons in 2009 (MAFRA,

*Corresponding author: wooyh612@korea.kr

Received September 24, 2021; Revised October 16, 2021;

Accepted October 25, 2021
2019). It is well known that increasing $\mathrm{CO}_{2}$ concentration positively improves leaf photosynthesis and thus productivity. The concentration of $\mathrm{CO}_{2}$ in the greenhouse can be lower than the concentration in the atmosphere when the greenhouse is not ventilated during winter, resulting in a considerable yield decrease. Therefore, a proper $\mathrm{CO}_{2}$ control system that reflects the variation of growth environments depending on greenhouse types and crop growth stages needs to be developed. A previous study suggested optimal setpoints for indoor $\mathrm{CO}_{2}$ concentration (Peet and Willits, 1987); however, 
Eun-Young Choi, Young-Ae Jeong, Seung-Hyun An, Dong-Cheol Jang, Dae-Hyun Kim, Dong-Soo Lee, Jin-Kyung Kwon, and Young-Hoe Woo

the estimated optimal $\mathrm{CO}_{2}$ concentration varies depending on ventilation, wind speed, or window aperture (Nederhoff, 1987; Sanchez-Guerrero et al., 2005). Also, cost-efficient control of $\mathrm{CO}_{2}$ supplies is necessary since pure $\mathrm{CO}_{2}$ is expensive. A proper $\mathrm{CO}_{2}$ control system may need to replenish $\mathrm{CO}_{2}$ concentration to maintain leaf photosynthesis effectively under different temperatures and radiation.

There is a model that describes leaf photosynthesis efficiency enhanced by the increased $\mathrm{CO}_{2}$ concentration (Farquhar et al., 1980). The rate of $\mathrm{CO}_{2}$ assimilation in plants depends on biochemical processes, light intensity, temperature, and $\mathrm{CO}_{2}$ concentration in the cytoplasm, thylakoid membrane, stroma, mitochondria. The most common methods used to understand $\mathrm{C}_{3}$ photosynthesis reactions are models of photosynthesis developed by Farquhar et al. (1980). In this model, the rate of photosynthesis may vary depending on the state of ribulose 1,5-bisphosphate carboxylase/oxygenase (Rubisco) that supplies sufficient ribulose 1,5-bisphosphate (RuBP), known as the Rubisco-limited photosynthesis rate, and occurs in low $\mathrm{CO}_{2}$ concentrations. The photosynthesis rate can also depend on the regeneration rate of RuBP, which occurs under high $\mathrm{CO}_{2}$ conditions. Rubisco and RuBP restrictions typically occur at $<20 \mathrm{~Pa}(-200 \mathrm{ppm}) \mathrm{CO}_{2}$ and at $>30 \mathrm{~Pa} \mathrm{CO}_{2}$, respectively. The triose phosphate use (TPU) limiting factor can set the maximum photosynthesis rate $\left(\mathrm{A}_{\max }\right)$ by increasing the $\mathrm{CO}_{2}$ rate or oxygen concentration (Sharkey, 1985). Plant photosynthetic capacity is, therefore, determined by the maximum rate of Rubisco carboxylation $\left(\mathrm{V}_{\text {cmax }}\right)$ and the maximum rate of electron transport $\left(\mathrm{J}_{\max }\right)$ at a reference temperature (generally $25^{\circ} \mathrm{C}$ ) using the response of $\mathrm{A}_{n}$ to intercellular $\mathrm{CO}_{2}$ concentration $\left(\mathrm{A}-\mathrm{C}_{\mathrm{i}}\right.$ response curves). The parameters estimated from the analysis of an A- $\mathrm{C}_{\mathrm{i}}$ curve respond to measurement temperature; thus, comparisons between two treatments are often made at a single temperature. Representative temperature responses of the fitted parameters are used to adjust these values to a single temperature, in this case, at $25^{\circ} \mathrm{C}$ (Sharkey et al., 2007). The $\mathrm{C}_{3}$ photosynthesis model proposed by Farquhar et al. (1980) has been applied to estimate leaf photosynthesisdependent temperature (Medlyn et al., 2002a; Kattge and Knorr, 2007) since the biochemical processes are temperaturedependent (Harley et al., 1992; Leuning, 2002; Medlyn et al., 2002b). Net $\mathrm{CO}_{2}$ uptake for photosynthesis depends on growth temperature (Hikosaka et al., 2006; Sage and Kubien, 2007). Recently, Kim et al. (2020) estimate heat stress reduction of cucumber plants by solar shading in a greenhouse by measuring and analyzing physiological conditions, such as leaf temperature, leaf-air temperature, $\mathrm{V}_{\mathrm{cmax}}, \mathrm{J}_{\max }$, thermal breakdown, and leaf respiration.

This study aimed to estimate photosynthetic capacity for tomato plants grown in a semi-closed greenhouse using temperature response models of plant photosynthesis by calculating $\mathrm{V}_{\text {cmax }}, \mathrm{J}_{\max }$, thermal breakdown, and leaf respiration to predict optimal conditions of the $\mathrm{CO}_{2}$-controlled greenhouse to maximize photosynthetic rate.

\section{Materials and Methods}

\section{Plant Growth Environments}

This study was conducted by growing tomatoes in a semi-closed greenhouse with hydroponics under integrated solar radiation (ISR)-automated irrigation. The tomatoes (Solanum lycopericum L. 'Dafnis') were transplanted onto coconut coir substrates ((Chip:Dust, 7:3), DY GS, Korea) on March 23, 2021. One dripper per plant was installed to supply a uniform feeding amount for each crop, and the tomato nutrient solution developed by RDA was provided to the automatic feeding system ((Macro-nutrients $\left(\mathrm{me} \mathrm{L}^{-1}\right)$ : $\mathrm{NO}_{3}-\mathrm{N}$ (8.2), $\mathrm{NH}_{4}-\mathrm{N}$ (1.4), P (2.0), K (5.0), $\mathrm{Ca}$ (4.0), $\mathrm{Mg}$ (2.0), $\mathrm{SO}_{4}-\mathrm{S}$ (2.0), Micro-nutrients (ppm): $\mathrm{Fe}$ (3.0), $\mathrm{Cu}$ (0.02), B (0.5), Mn (0.5), Zn (0.05), Mn(0.01)). The electrical conductivity and $\mathrm{pH}$ were controlled at $2.0-2.5 \mathrm{dS} \cdot \mathrm{m}^{-1}$ and $5.3-6.8$, respectively. The tomatoes were trained into a one-stem vine. The shading screen was closed between 11 a.m. and $2 \mathrm{p} . \mathrm{m}$. when the light intensity reached $700 \mathrm{~W} \cdot \mathrm{m}^{-2}$ in the greenhouse and the air temperature was more than $30^{\circ} \mathrm{C}$. During the experimental period, the minimum night temperature was set to $18^{\circ} \mathrm{C}$, and the day temperature was set to $23^{\circ} \mathrm{C}$. The internal and external environments of the greenhouse (e.g., temperature, humidity, solar radiation, and $\mathrm{CO}_{2}$ ) were measured beginning May 7, 2021 using a greenhouse environmental control system (Magma 3.0, GreenCS, Jeonnam, Korea). The ISR was set to $100 \mathrm{~J} \cdot \mathrm{cm}^{-2}$ from the first irrigation to the end, and the water volume per plant in a day was 1.5-2.0L. Tomato harvesting was carried out beginning May 23, two months after the transplant, and a 12 
Comparison of Measured and Calculated Carboxylation Rate, Electron Transfer Rate and Photosynthesis Rate Response to Different ...

to 18 leaf number was maintained by removing the old leaves once a week. The apical shoot was placed approximately 2.5 to 3.0 meters above the gutter.

In this experiment, all the measurements were conducted with the plants that its plant height was $271( \pm 8.20) \mathrm{cm}, 343$ $( \pm 6.51) \mathrm{cm}$ and $416( \pm 5.74) \mathrm{cm}$ at June 22 , July 14 , and August 3, 2021, respectively with the $7.8( \pm 0.37), 10.8( \pm 0.20)$ and $13.4( \pm 0.40)$ of cluster number, the $39.0( \pm 1.05), 43.9$ $( \pm 1.51)$ and $42.0( \pm 2.30)$ of leaf length and $33.2( \pm 5.06), 39.3$ $( \pm 2.42)$ and $36.9( \pm 5.12)$ of leaf width of fifth leaves from the apical region at June 22, July 14, and August 3, 2021, respectively.

\section{Measurements}

Total 16 replications of gas exchange measurements were conducted with a portable infrared gas analyzer system (LI-6400XT; Li-Cor, Inc., Lincoln, NE, USA) during the June 22 to August 9, 2021. One of the youngest fully expanded leaflets on the fifth leaf of the apical shoot was placed in the leaf chamber of gas analyzer. For the $A-C_{i}$ curve response to $\mathrm{CO}_{2}$ level, the reference $\mathrm{CO}_{2}$ for the $A-C_{i}$ curves was changed in the following order: 50, 100, 200, $300,600,800,1000,1500$, and $1800 \mu \mathrm{mol} \cdot \mathrm{mol}^{-1}$ at the PAR values of $200,400,600,800,1000,1200$, and $1500 \mu \mathrm{mol} \cdot \mathrm{m}^{-2} \cdot \mathrm{s}^{-1}$ with the $34.54^{\circ} \mathrm{C}$ average air temperature. For the $A-C_{i}$ curve response to different leaf temperatures, the leaf temperature was increased from $20^{\circ} \mathrm{C}$ to $35^{\circ} \mathrm{C}$ with $5^{\circ} \mathrm{C}$ increments, and $\mathrm{A}-\mathrm{C}_{\mathrm{i}}$ response curves were recorded at each temperature and the reference $\mathrm{CO}_{2}$ levels and a $700 \mu \mathrm{mol} \cdot \mathrm{m}^{-2} \cdot \mathrm{s}^{-1}$ PAR value. The significance between environmental factors was analyzed with variable selection stepwise using the SAS 9.2 software package (SAS Institute, Cary, NC, USA).

\section{Comparison of Observed and Estimated Responses to Different Light Intensity and Temperature}

We used the Arrhenius equation to describe the kinetic temperature responses of $\mathrm{V}_{\mathrm{cmax}}$ and $\mathrm{J}_{\max }$. Arrhenius function, $\mathrm{V}_{\text {cmax }}, \mathrm{J}_{\max }$, thermal breakdown, $\mathrm{R}_{\mathrm{d}}$ were calculated using the selected model. The program was developed using SAS (SAS Institute Inc 9.1, Cary, NC, USA). Relationships among $\mathrm{V}_{\mathrm{cmax}}, \mathrm{J}_{\max }$, and other environmental factors were analyzed stepwise.

The Arrhenius function is as follows:

$$
f\left(T_{l}\right)=\exp \left[\frac{\Delta H_{a}}{298.15 R}\left(1-\frac{298.15}{T_{l}}\right)\right]
$$

where $T_{l}$ is leaf temperature, $\mathrm{R}$ is the universal gas

Table 1. Maximum (Max), minimum (Min), and average (Av) of air temperature, relative humidity, leaf temperature, solar radiation, and $\mathrm{CO}_{2}$ concentration in a semi-closed greenhouse for tomato cultivation from June 22 to August 9, 2021.

\begin{tabular}{|c|c|c|c|c|c|c|c|c|c|c|c|c|c|c|}
\hline \multirow[t]{2}{*}{ Month } & \multicolumn{3}{|c|}{$\begin{array}{c}\text { Air } \\
\text { temperature } \\
\left({ }^{\circ} \mathrm{C}\right)\end{array}$} & \multicolumn{3}{|c|}{$\begin{array}{l}\text { Relative } \\
\text { humidity } \\
(\%)\end{array}$} & \multicolumn{3}{|c|}{$\begin{array}{c}\text { Leaf } \\
\text { temperature } \\
\left({ }^{\circ} \mathrm{C}\right) \\
\end{array}$} & \multicolumn{2}{|c|}{$\begin{array}{c}\text { Solar } \\
\text { Irradiance } \\
\left(\mathrm{W} \cdot \mathrm{m}^{-2} \cdot \mathrm{s}^{-1}\right) \\
\end{array}$} & \multicolumn{3}{|c|}{$\begin{array}{c}\mathrm{CO}_{2} \\
(\mathrm{ppm})\end{array}$} \\
\hline & Max & Min & $\mathrm{Av}$ & Max & Min & $\mathrm{Av}$ & Max & Min & $\mathrm{Av}$ & $\operatorname{Max}$ & $\mathrm{Av}$ & Max & Min & $\mathrm{Av}$ \\
\hline June & 32.3 & 15.1 & $22.7 \pm 0.7$ & 100 & 44.8 & $86 \pm 1.9$ & 24.1 & 22.1 & $23.4 \pm 0.3$ & 1175 & $322 \pm 46$ & 825 & 310 & $521 \pm 17$ \\
\hline July & 34.7 & 18.7 & $24.8 \pm 3.4$ & 100 & 60.9 & $90.9 \pm 8.4$ & 34.3 & 17.9 & $23.9 \pm 2.9$ & 1149 & $303 \pm 250$ & 2000 & 206 & $520 \pm 268$ \\
\hline August & 35.0 & 19.8 & $25.2 \pm 3.2$ & 100 & 61.0 & $84.6 \pm 10.6$ & 32.5 & 19.6 & $23.6 \pm 2.6$ & 1032 & $323 \pm 243$ & 576 & 275 & $452 \pm 70$ \\
\hline
\end{tabular}

Table 2. Photosynthetic parameter values for equations for the mean $V_{c m a x}$ and $J_{\max }$.

\begin{tabular}{cccc}
\hline \hline Outputs & Vcmax & Jmax & Unit $^{-1}$ \\
\hline$\Delta$ Ha & 58,520 & 37,000 & $\mathrm{~J} \cdot \mathrm{mol}^{-1}$ \\
$\Delta$ Hd & 149,250 & 152,040 & $\mathrm{~J} \cdot \mathrm{mol}^{-1}$ \\
$\Delta \mathrm{S}$ & 485 & 495 & $\mathrm{~J} \cdot \mathrm{mol}^{-1} \cdot \mathrm{K}^{-1}$ \\
\hline
\end{tabular}

$\Delta \mathrm{Ha}$ : activation energy

$\Delta H_{d}$ : energy of deactivation

$\Delta S$ : entropy 
Eun-Young Choi, Young-Ae Jeong, Seung-Hyun An, Dong-Cheol Jang, Dae-Hyun Kim, Dong-Soo Lee, Jin-Kyung Kwon, and Young-Hoe Woo

constant $\left(8.314 \mathrm{~J} \cdot \mathrm{K}^{-1} \cdot \mathrm{mol}^{-1}\right)$, and $\Delta H_{\mathrm{a}}$ is the activation energy $\left(\mathrm{J} \cdot \mathrm{mol}^{-1}\right)$. Parameter values for $\mathrm{V}_{\mathrm{cmax}}$ and $\mathrm{J}_{\max }$ are presented in Table 2 (Farquhar et al., 1980; Leuning, 2002; Caemmerer, 2000).

The $\mathrm{V}_{\mathrm{cmax}}$ is calculated as follows:

$$
V_{c \max }=\frac{V_{m, 25} \exp \left[0.088\left(T_{l}-25\right)\right]}{1+\exp \left[0.29\left(T_{l}-41\right)\right]}
$$

where, $V_{m, 25}$ is the carboxylation rate at $25^{\circ} \mathrm{C}\left(\mu \mathrm{mol} \cdot \mathrm{m}^{-2} \cdot \mathrm{s}^{-1}\right)$, 0.088 is temperature coefficient for that parameter at $25^{\circ} \mathrm{C}$ and 0.29 is temperature coefficient for that parameter at $41^{\circ} \mathrm{C}$ (Campbell and Norman, 1998).

The $\mathrm{J}_{\max }$ is calculated as follows:

$$
\begin{aligned}
& J_{\max }=J_{\max 25} f\left(T_{l}\right) f_{H}\left(T_{l}\right) \\
& J_{\max 25}=1.67 V_{\text {cmax } 25}
\end{aligned}
$$

where, $f_{H}$ is the deactivation energy $\left[\mathrm{J} \cdot \mathrm{mol}^{-1}\right]$

$$
J_{\max 25} / V_{\text {cmax } 25}=1.67
$$

where Medlyn et al. (2002b) derived this equation at $25^{\circ} \mathrm{C}$ using Bernacchi et al. (2001).

The thermal breakdown is calculated as follows:

$$
f H\left(T_{l}\right)=\frac{1+\exp \left(\frac{298.15 \Delta S-\Delta H_{d}}{298.15 R}\right)}{1+\exp \left(\frac{\Delta S T_{l}-\Delta H_{d}}{R T_{l}}\right)}
$$

where, $\Delta S$ is the entropy $\left(\mathrm{JK}^{-1} \cdot \mathrm{mol}^{-1}\right)$ and $\Delta H_{d}$ is the energy of deactivation $\left(\mathrm{J} \cdot \mathrm{mol}^{-1}\right)$.

The leaf $R_{d}$ is calculated as follows:

$$
R_{d}=\frac{R_{d, 25} \exp \left[0.069\left(T_{l}-25\right)\right]}{1+\exp \left[1.3\left(T_{l}-41\right)\right]}
$$

where, $R_{d, 25}$ is the leaf respiration at $25^{\circ} \mathrm{C}\left(\mu \mathrm{mol} \cdot \mathrm{m}^{-2} \cdot \mathrm{s}^{-1}\right)$, and leaf respiration is typically $1 \%-2 \%$ of $\mathrm{V}_{\mathrm{cmax}}$ (Caemmerer, 2000).

$A_{n}$ is calculated as follows;

$$
\begin{aligned}
& A_{n}=(1-0.5 \Phi) V_{c}-R_{d} \\
& \Phi=\frac{V_{o}}{V_{c}}=\left(\frac{V_{\text {omax }}}{V_{\text {cmax }}} \frac{K_{c}}{K_{o}}\right) \frac{O_{a}}{C_{i}}=\frac{O_{a}}{T C_{i}}=\frac{210,000}{2,600 C_{i}}
\end{aligned}
$$

where $V_{c}$ is considered as the $\mathrm{V}_{\mathrm{cmax}}, R_{d 25}=0.015 V_{\text {cmax } 25}$ at $25^{\circ} \mathrm{C}$ (frequently used for $\mathrm{C}_{3}$ plants (Collatz et al., 1991)), $\mathrm{V}_{\mathrm{cmax}, 25}=78.2 \mu \mathrm{mol} \cdot \mathrm{m}^{-2} \cdot \mathrm{s}^{-1}$ for $\mathrm{C}_{3}$ plant, herbaceous $\mathrm{C}_{\mathrm{i}}=$ $245 \mu \mathrm{mol} \cdot \mathrm{mol}^{-1}$ for $\mathrm{C}_{3}$ plant, and $R_{d}=0.015 \times 78.2 \times f\left(T_{l}\right)$ $\times f H\left(T_{l}\right), \Phi=210000 /(2600 \times 245)$.

\section{Results and Discussion}

The average air temperature was $22.7^{\circ} \mathrm{C}, 24.8^{\circ} \mathrm{C}$, and

\begin{tabular}{|c|c|c|c|}
\hline Outputs & At leaf temperature $(n=5)$ & Normalized to $25^{\circ} \mathrm{C}(\mathrm{n}=5)$ & Calculated at $25^{\circ} \mathrm{C}(\mathrm{n}=51)$ \\
\hline $\mathrm{V}_{\mathrm{cmax}}^{\mathrm{z}}\left(\mu \mathrm{mol} \cdot \mathrm{m}^{-2} \cdot \mathrm{s}^{-1}\right)$ & $102( \pm 14)^{x}$ & $87.51( \pm 7.485)$ & $84.29( \pm 0.864)$ \\
\hline $\mathrm{J}^{\mathrm{y}}\left(\mu \mathrm{mol} \cdot \mathrm{m}^{-2} \cdot \mathrm{s}^{-1}\right)$ & $126( \pm 10)$ & $115( \pm 6.178)$ & $133( \pm 0.423)$ \\
\hline $\mathrm{TPU}\left(\mu \mathrm{mol} \cdot \mathrm{m}^{-2} \cdot \mathrm{s}^{-1}\right)$ & $9.163( \pm 0.722)$ & $8.423( \pm 0.488)$ & \\
\hline $\mathrm{R}_{\mathrm{d}}\left(\mu \mathrm{molCO}{ }_{2} \cdot \mathrm{m}^{-2} \cdot \mathrm{s}^{-1}\right)$ & $4.658( \pm 0.563)$ & $4.228( \pm 0.448)$ & $1.338( \pm 0.021)$ \\
\hline$f\left(\mathrm{~T}_{l}\right)$ (relative value) & & & $1.090( \pm 0.012)$ \\
\hline$f_{\mathrm{H}}\left(\mathrm{T}_{l}\right)$ (relative value) & & & $0.940( \pm 0.008)$ \\
\hline
\end{tabular}
$25.2^{\circ} \mathrm{C}$ for June, July, and August, respectively, and the average leaf temperature was slightly lower than the air temperature in July and August. The maximum and average levels of solar irradiance were 1,175 and $323 \mathrm{~W} \cdot \mathrm{m}^{-2} \cdot \mathrm{s}^{-1}$,

Table 3. Comparison of Rubisco maximum carboxylation rate $\left(\mathrm{V}_{\mathrm{cmax}}\right)$, maximum electron transport rate $\left(\mathrm{J}_{\max }\right)$, leaf respiration under daylight $\left(\mathrm{R}_{\mathrm{d}}\right)$ from gas exchange measurements and calculations and calculated Arrhenius function $\left[f\left(\mathrm{~T}_{l}\right)\right]$, and thermal breakdown $\left[f_{\mathrm{H}}\left(\mathrm{T}_{l}\right)\right]$ in a semi-closed greenhouse for tomato cultivation at the June 22 and July 14, 2021.

${ }^{\text {zy. }}$ Rubisco maximum carboxylation rate $\left(\mathrm{V}_{\text {cmax }}\right)$ and electrical transport rate $(\mathrm{J})$ from the $\mathrm{A}-\mathrm{C}_{\mathrm{i}}$ curve response to $\mathrm{CO}_{2}$ levels of 50, 100, 200, $300,600,800,1000,1500$, and $1800 \mu \mathrm{mol} \cdot \mathrm{mol}^{-1}$.

: Each value is the mean of five plants of five measurements at both June 22 and July 14, 2021. 
Comparison of Measured and Calculated Carboxylation Rate, Electron Transfer Rate and Photosynthesis Rate Response to Different ...

respectively. The maximum level of $\mathrm{CO}_{2}$ ranged between 576 and $825 \mathrm{ppm}$, and the extremely higher concentration, $2,000 \mathrm{ppm}$, was found only on a single day (Table 1).

$\mathrm{V}_{\mathrm{cmax}}$ and $\mathrm{J}_{\max }$ normalized to $25^{\circ} \mathrm{C}$ of the gas exchange measurement for the $\mathrm{A}-\mathrm{C}_{\mathrm{i}}$ curve response to $\mathrm{CO}_{2}$ level from June to July was 87.51 and $115 \mu \mathrm{mol} \cdot \mathrm{m}^{-2} \cdot \mathrm{s}^{-1}$, respectively with a similar value for the calculated $\mathrm{V}_{\mathrm{cmax}}$ at $84.29 \mu \mathrm{mol} \cdot \mathrm{m}^{-2} \cdot \mathrm{s}^{-1}$, and a higher calculated $\mathrm{J}_{\max }$ at $133 \mu \mathrm{mol} \cdot \mathrm{m}^{-2} \cdot \mathrm{s}^{-1}$ (Table 3). The thermal breakdown was 0.940 (relative value; R.V.), and the $\mathrm{R}_{\mathrm{d}}$ was 1.338 , which was 3 -fold lower than that normalized at $25^{\circ} \mathrm{C}$ from the gas exchange measurements, 4.228. The Arrhenius function $\left[\mathrm{f}\left(\mathrm{T}_{l}\right)\right]$ value was 1.09 .

While $25^{\circ} \mathrm{C}$-normalized $\mathrm{V}_{\text {cmax }}$, $\mathrm{J}$ and $\mathrm{R}_{\mathrm{d}}$ from gas exchange measurements and calculation increased according to the PAR values of $600,800,1000$, and $1200 \mu \mathrm{mol} \cdot \mathrm{m}^{-2} \cdot \mathrm{s}^{-1}$, both values declined at the PAR 1500 level, which may be due to the increased leaf temperature $\left(34.18^{\circ} \mathrm{C}\right)$ during the measurement, of which the estimated thermal breakdown $\left[\mathrm{fH}\left(\mathrm{T}_{l}\right)\right]$ value was the lowest at 0.584 (Table 4). The estimated Arrhenius function $\mathrm{f}\left(\mathrm{T}_{l}\right)$ value was 1.33 at PAR $600\left(30.78^{\circ} \mathrm{C}\right)$, 1.32 at PAR $800\left(30.82^{\circ} \mathrm{C}\right), 1.32$ at PAR $1000\left(30.75^{\circ} \mathrm{C}\right)$, 1.44 at PAR $1200\left(32.87^{\circ} \mathrm{C}\right)$, and 1.55 at PAR $1500\left(34.18^{\circ} \mathrm{C}\right)$. The Arrhenius function value indicates the growth response according to temperature, meaning there is a positive correlation between the values and sensitivity to temperature. The estimated $\mathrm{J}_{\max }$ declined from the PAR 1200 level, where the leaf temperature was measured at $32.87^{\circ} \mathrm{C}$.

The photosynthetic rates of the fifth leaves from the apical region were saturated at a light intensity of $1200 \mu \mathrm{mol} \cdot \mathrm{m}^{-2} \cdot \mathrm{s}^{-1}$ and reached the saturation point at a $\mathrm{CO}_{2}$ concentration of 1500 ppm (Fig. 1). The $\mathrm{CO}_{2}$ saturation point was reached at $\mathrm{CO}_{2} 600 \mathrm{ppm}$ for 200 and $400 \mu \mathrm{mol} \cdot \mathrm{m}^{-2} \cdot \mathrm{s}^{-1} \mathrm{PAR}, \mathrm{CO}_{2} 800 \mathrm{ppm}$ for 600 and $800 \mu \mathrm{mol} \cdot \mathrm{m}^{-2} \cdot \mathrm{s}^{-1} \mathrm{PAR}, \mathrm{CO}_{2} 1,000 \mathrm{ppm}$ for $1000 \mu \mathrm{mol} \cdot \mathrm{m}^{-2} \cdot \mathrm{s}^{-1} \mathrm{PAR}$, and $\mathrm{CO}_{2} 1500 \mathrm{ppm}$ for 1200 and $1500 \mu \mathrm{mol} \cdot \mathrm{m}^{-2} \cdot \mathrm{s}^{-1}$ PAR levels (Fig. 1). In the semi-closed greenhouse, average PAR level ranged about 400 and maximized $1060 \mu \mathrm{mol} \cdot \mathrm{m}^{-2} \cdot \mathrm{s}^{-1}$ during the day of August, indicating that supplementatal level for $\mathrm{CO}_{2}$ can be raised by the range between 600 and $1000 \mathrm{ppm}$ to maximize photosynthesis rate in the light intensity of semi-closed greenhouse.

Table 5. shows the leaf temperature dependence of $\mathrm{V}_{\mathrm{cmax}}$ and $\mathrm{J}_{\max }$. While $25^{\circ} \mathrm{C}$-normalized $\mathrm{V}_{\mathrm{cmax}}$ increased with leaf
Table 4. Comparison of Rubisco maximum carboxylation rate $\left(\mathrm{V}_{\mathrm{cmax}}\right)$, maximum electron transport rate $\left(\mathrm{J}_{\max }\right)$, leaf respiration under daylight $\left(\mathrm{R}_{\mathrm{d}}\right)$ from gas exchange measurements and calculations and calculated Arrhenius function $\left[f\left(\mathrm{~T}_{l}\right)\right]$, and thermal breakdown $\left[f_{\mathrm{H}}\left(\mathrm{T}_{l}\right)\right]$ with light intensity in a semi-closed greenhouse for tomato cultivation.

\begin{tabular}{|c|c|c|c|}
\hline & 30.78 & PAR 600 & \\
\hline $\mathrm{V}_{\mathrm{cmax}}^{\mathrm{z}}$ & 128 & 77.39 & $95( \pm 0.113)$ \\
\hline $\mathrm{J}^{\mathrm{y}}$ & 131 & 93.59 & $132( \pm 0.304)$ \\
\hline TPU & 9.53 & 7.23 & - \\
\hline $\mathrm{R}_{\mathrm{d}}$ & 5.44 & 3.80 & $1.76( \pm 0.013)$ \\
\hline$f\left(\mathrm{~T}_{\mathrm{L}}\right)$ & - & - & $1.33( \pm 0.007)$ \\
\hline \multirow[t]{2}{*}{$f_{\mathrm{H}}\left(\mathrm{T}_{\mathrm{L}}\right)$} & - & - & $0.760( \pm 0.005)$ \\
\hline & 30.82 & PAR 800 & \\
\hline $\mathrm{V}_{\mathrm{cmax}}$ & 127 & 77 & $95( \pm 0.030)$ \\
\hline $\mathrm{J}$ & 139 & 99 & $132( \pm 0.057)$ \\
\hline TPU & 9.70 & 7.4 & - \\
\hline $\mathrm{R}_{\mathrm{d}}$ & 4.30 & 3.00 & $1.75( \pm 0.003)$ \\
\hline$f\left(\mathrm{~T}_{l}\right)$ & - & - & $1.32( \pm 0.001)$ \\
\hline \multirow[t]{2}{*}{$f_{\mathrm{H}}\left(\mathrm{T}_{l}\right)$} & - & - & $0.770( \pm 0.001)$ \\
\hline & 30.75 & PAR 1000 & \\
\hline $\mathrm{V}_{\mathrm{cmax}}$ & 148 & 89.43 & $95( \pm 0.112)$ \\
\hline $\mathrm{J}$ & 159 & 114 & $133( \pm 0.196)$ \\
\hline TPU & 11.21 & 8.50 & - \\
\hline $\mathrm{R}_{\mathrm{d}}$ & 5.15 & 3.60 & $1.74( \pm 0.009)$ \\
\hline$f\left(\mathrm{~T}_{l}\right)$ & - & - & $1.32( \pm 0.005)$ \\
\hline \multirow[t]{2}{*}{$f_{\mathrm{H}}\left(\mathrm{T}_{l}\right)$} & - & - & $0.770( \pm 0.004)$ \\
\hline & 32.87 & PAR 1200 & \\
\hline $\mathrm{V}_{\mathrm{cmax}}$ & 180.3 & 108.9 & $96( \pm 0.058)$ \\
\hline $\mathrm{J}$ & 179.6 & 128.0 & $126( \pm 1.014)$ \\
\hline TPU & 12.5 & 9.5 & - \\
\hline $\mathrm{R}_{\mathrm{d}}$ & 5.9 & 4.1 & $1.99( \pm 0.031)$ \\
\hline$f\left(\mathrm{~T}_{l}\right)$ & - & - & $1.44( \pm 0.016)$ \\
\hline \multirow[t]{2}{*}{$f_{\mathrm{H}}\left(\mathrm{T}_{l}\right)$} & - & - & $0.670( \pm 0.013)$ \\
\hline & 34.18 & PAR 1500 & \\
\hline $\mathrm{V}_{\mathrm{cmax}}$ & 216 & 98 & $95( \pm 0.049)$ \\
\hline $\mathrm{J}$ & 176 & 104 & $118( \pm 0.205)$ \\
\hline TPU & 12.1 & 8.9 & - \\
\hline $\mathrm{R}_{\mathrm{d}}$ & 5.49 & 3.14 & $2.20( \pm 0.005)$ \\
\hline$f\left(\mathrm{~T}_{l}\right)$ & - & - & $1.55( \pm 0.003)$ \\
\hline$f_{\mathrm{H}}\left(\mathrm{T}_{l}\right)$ & - & - & $0.584( \pm 0.002)$ \\
\hline
\end{tabular}

${ }^{\mathrm{zy}}$ : Rubisco maximum carboxylation rate $\left(\mathrm{V}_{\mathrm{cmax}}\right)$ and electrical transport rate $(\mathrm{J})$ from the $\mathrm{A}-\mathrm{C}_{\mathrm{i}}$ curve response to $\mathrm{CO}_{2}$ level, 50, $100,200,300,600,800,1000,1500$, and $1800 \mu \mathrm{mol} \cdot \mathrm{mol}^{-1}$ at PAR values of $200,400,600,800,1000,1200$, and $1500 \mu \mathrm{mol} \cdot \mathrm{m}^{-2} \cdot \mathrm{s}^{-1}$ with with the $34.54^{\circ}$ average air temperature. 
Eun-Young Choi, Young-Ae Jeong, Seung-Hyun An, Dong-Cheol Jang, Dae-Hyun Kim, Dong-Soo Lee, Jin-Kyung Kwon, and Young-Hoe Woo

temperature from 20 to $33^{\circ} \mathrm{C}$, the $\mathrm{J}$ declined at the $33^{\circ} \mathrm{C}$ leaf temperature. Our estimates of $\mathrm{V}_{\mathrm{cmax}}$ and $\mathrm{J}_{\max }$ were close to the measurements with the declined $\mathrm{J}_{\max }$ at the leaf temperature higher than $30^{\circ} \mathrm{C}$, and a leaf temperature optimum for the estimated $\mathrm{J}_{\max }$ was $30^{\circ} \mathrm{C}$ (Table 5). Leuning (2002) examined the temperature-dependent $\mathrm{V}_{\mathrm{cmax}}$ and $\mathrm{J}_{\max } \mathrm{using}$ published datasets and showed a high variability of $\mathrm{J}_{\max } / \mathrm{V}_{\mathrm{cmax}}$ between and within species at leaf temperature $>30^{\circ} \mathrm{C}$ with $\mathrm{J}_{\max 0} / \mathrm{V}_{\mathrm{cmax} 0}=2 \cdot 00 \pm 0 \cdot 60(\mathrm{SD}, \mathrm{n}=43)$, at leaf temperature $=$ $25^{\circ} \mathrm{C}$ with a temperature optimum near $40^{\circ} \mathrm{C}$ for $\mathrm{V}_{\mathrm{cmax}}$, and $35^{\circ} \mathrm{C}$ for $\mathrm{J}_{\max }$ of cotton plant (Harley et al., 1992). The Arrhenius function $\left[\mathrm{f}\left(\mathrm{T}_{l}\right)\right]$ value was in the order of 0.772 at $20^{\circ} \mathrm{C},<0.984$ at $25^{\circ} \mathrm{C},<1.219$ at $30^{\circ} \mathrm{C}$, and $<1.466$ at $33^{\circ} \mathrm{C}$ of leaf temperature. The thermal breakdown $\left[\mathrm{fH}\left(\mathrm{T}_{l}\right)\right]$ value was in the order of 1.102 at $20^{\circ} \mathrm{C}>1.008$ at $25^{\circ} \mathrm{C}>0.847$ at $30^{\circ} \mathrm{C}>0.651$ at $33^{\circ} \mathrm{C}$ of leaf temperature. The calculated $\mathrm{R}_{\mathrm{d}}$ increased according to the leaf temperature. In this experiment, the leaf temperature was increased from $20^{\circ} \mathrm{C}$ to $35^{\circ} \mathrm{C}$ with $5^{\circ} \mathrm{C}$ increment and $\mathrm{A}-\mathrm{C}_{\mathrm{i}}$ response curves were recorded at each temperature; however, at least $10 \mathrm{~min}$ of steady state at

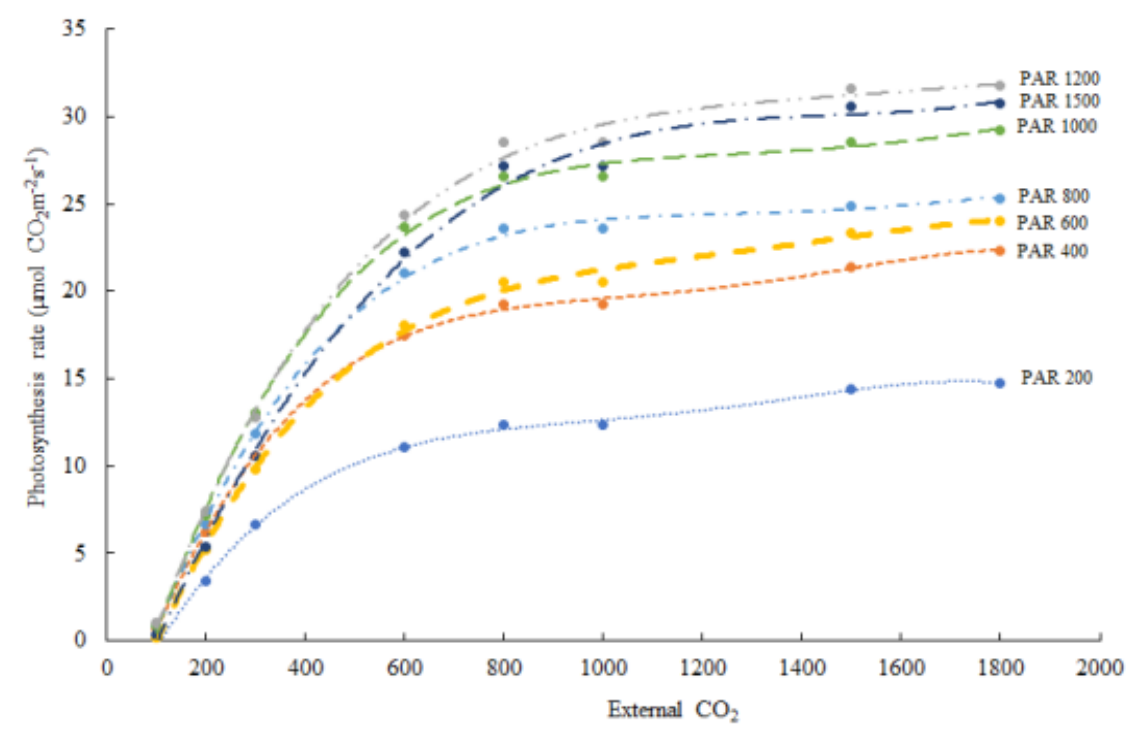

Fig. 1. Photosynthesis rate response to different light intensity. The reference $\mathrm{CO}_{2}$ was changed in the following order: 50, 100, 200, 300, 600, 800, 1000,1500 , and $1800 \mu \mathrm{mol} \cdot \mathrm{m}^{-2} \cdot \mathrm{s}^{-1}$ at the PAR value from 200 to $1500 \mu \mathrm{mol} \cdot \mathrm{m}^{-2} \cdot \mathrm{s}^{-1}$ with the air ambient temperature.

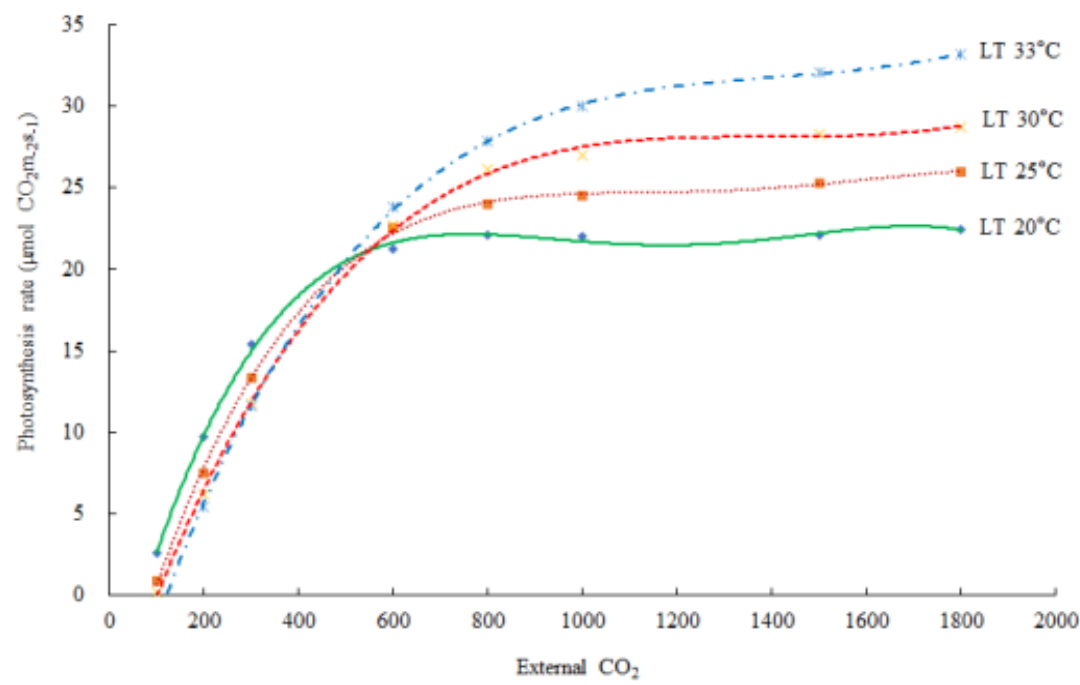

Fig. 2. Photosynthesis rate response to different the leaf temperature increased from $20^{\circ} \mathrm{C}$ to $35^{\circ} \mathrm{C}$ with $5^{\circ} \mathrm{C}$ increment and $\mathrm{A}-\mathrm{C}_{\mathrm{i}}$ response curves were recorded at each temperature after at least $10 \mathrm{~min}$ of steady state at the reference $\mathrm{CO}_{2}$ levels and at a $700 \mu \mathrm{mol} \cdot \mathrm{m}^{-2} \cdot \mathrm{s}^{-1} \mathrm{PAR}$ value. 
Comparison of Measured and Calculated Carboxylation Rate, Electron Transfer Rate and Photosynthesis Rate Response to Different ...

the reference $\mathrm{CO}_{2}$ levels should not have, resulting to maximum $33^{\circ} \mathrm{C}$ of leaf temperature (Fig. 2). The estimated An decreased at the high leaf temperature. The extimated photosynthetic rates were saturated at al leaf temperature of $32.4^{\circ} \mathrm{C}$ (Fig. 3)

Table 5. Comparison of Rubisco maximum carboxylation rate $\left(\mathrm{V}_{\mathrm{cmax}}\right)$, maximum electron transport rate $\left(\mathrm{J}_{\max }\right)$, leaf respiration under daylight $\left(\mathrm{R}_{\mathrm{d}}\right)$ from gas exchange measurements and calculations and calculated Arrhenius function $\left[f\left(\mathrm{~T}_{l}\right)\right]$, and thermal breakdown $\left[f_{\mathrm{H}}\left(\mathrm{T}_{l}\right)\right]$ with different leaf temperatures in a semi-closed greenhouse for tomato cultivation.

\begin{tabular}{|c|c|c|c|}
\hline \multicolumn{4}{|c|}{ Outputs At Leaf Temperature Normalized to $25^{\circ} \mathrm{C}$ Calculated at $25^{\circ} \mathrm{C}$} \\
\hline \multicolumn{4}{|c|}{$20^{\circ} \mathrm{C}$} \\
\hline $\mathrm{V}_{\mathrm{cmax}}^{\mathrm{z}}$ & 72 & 113 & $56.86( \pm 0.061)$ \\
\hline $\mathrm{J}^{\mathrm{y}}$ & 128 & 174 & $111( \pm 0.067)$ \\
\hline TPU & 9.3 & 13.0 & \\
\hline $\mathrm{R}_{\mathrm{d}}$ & 5.6 & 7.7 & $0.836( \pm 0.001)$ \\
\hline$f\left(\mathrm{~T}_{l}\right)$ & & & $0.772( \pm 0.001)$ \\
\hline$f_{\mathrm{H}}\left(\mathrm{T}_{l}\right)$ & & & $1.102( \pm 0.000)$ \\
\hline \multicolumn{4}{|c|}{$25^{\circ} \mathrm{C}$} \\
\hline $\mathrm{V}_{\mathrm{cmax}}$ & 124 & 126 & $76.80( \pm 1.210)$ \\
\hline $\mathrm{J}$ & 159 & 160 & $129( \pm 0.971)$ \\
\hline TPU & 11.1 & 11.3 & \\
\hline $\mathrm{R}_{\mathrm{d}}$ & 8.1 & 8.2 & $1.16( \pm 0.021)$ \\
\hline$f\left(\mathrm{~T}_{l}\right)$ & & & $0.984( \pm 0.014)$ \\
\hline$f_{\mathrm{H}}\left(\mathrm{T}_{l}\right)$ & & & $1.008( \pm 0.007)$ \\
\hline \multicolumn{4}{|c|}{$30^{\circ} \mathrm{C}$} \\
\hline $\mathrm{V}_{\mathrm{cmax}}$ & 213 & 149 & $91.39( \pm 1.489)$ \\
\hline $\mathrm{J}$ & 195 & 153 & $134( \pm 0.320)$ \\
\hline TPU & 13.0 & 10.5 & \\
\hline $\mathrm{R}_{\mathrm{d}}$ & 11.1 & 8.6 & $1.565( \pm 0.052)$ \\
\hline$f\left(\mathrm{~T}_{l}\right)$ & & & $1.219( \pm 0.029)$ \\
\hline$f_{\mathrm{H}}\left(\mathrm{T}_{l}\right)$ & & & $0.847( \pm 0.022)$ \\
\hline \multicolumn{4}{|c|}{$33^{\circ} \mathrm{C}$} \\
\hline $\mathrm{V}_{\mathrm{cmax}}$ & 318 & 161 & $95.76( \pm 0.202)$ \\
\hline $\mathrm{J}$ & 231 & 146 & $124( \pm 1.847)$ \\
\hline TPU & 15.8 & 11.6 & \\
\hline $\mathrm{R}_{\mathrm{d}}$ & 15.6 & 9.6 & $2.03( \pm 0.058)$ \\
\hline$f\left(\mathrm{~T}_{l}\right)$ & & & $1.466( \pm 0.029)$ \\
\hline$f_{\mathrm{H}}\left(\mathrm{T}_{l}\right)$ & & & $0.651( \pm 0.024)$ \\
\hline
\end{tabular}

${ }^{\text {zy: }}$ Rubisco maximum carboxylation rate $\left(\mathrm{V}_{\mathrm{cmax}}\right)$ and electrical transport rate $(\mathrm{J})$ from the $\mathrm{A}-\mathrm{C}_{\mathrm{i}}$ curve response to different leaf temperatures, the leaf temperature was increased from $20^{\circ} \mathrm{C}$ to $35^{\circ} \mathrm{C}$ with $5^{\circ} \mathrm{C}$ increment and $\mathrm{A}-\mathrm{C}_{\mathrm{i}}$ response curves were recorded at each temperature with $700 \mu \mathrm{mol} \cdot \mathrm{m}^{-2} \cdot \mathrm{s}^{-1} \mathrm{PAR}$ value.
According to the multiple regression analysis by the stepwise variable selection method, the partial R-square for the $\mathrm{V}_{\text {cmax }}$, a dependent variable, was larger with the leaf temperature $(0.9860)$ than the other factors, $\mathrm{J}_{\max }(0.0123)$ or air temperature (0.0001) (Table 6). When the $A_{n}$, net photosynthesis rate, was set as a dependent variable, the partial R-square was also larger with the leaf temperature ( 0.9860$)$, followed by calculated leaf respiration $(0.011)$ (Table 7). The dependence of $\mathrm{V}_{\mathrm{cmax}}$ on temperature has been described by an Arrhenius function since it increases over a wide range of temperatures and does not deactivate until very high, near-lethal temperatures $\left(>50^{\circ} \mathrm{C}\right)$ (Leuning, 2002). Medlyn et al. (2002a) showed apparent species differences in comparing the responses of $\mathrm{J}_{\max }$ to temperature from different studies. Further study is necessary to determine whether $\mathrm{J}_{\max }$ temperature responses differ by elevated growth $\mathrm{CO}_{2}$ levels. Estimated $\mathrm{J}_{\max }, \mathrm{A}_{\mathrm{n}}$, and thermal breakdown decreased due to increased leaf temperature $(>$ $30^{\circ} \mathrm{C}$ ). The photosynthetic rates of the fifth leaves from the

Table 6. Partial R-Square and multiple regression analysis stepwise between calculated $\mathrm{V}_{\mathrm{cmax}}$ and $\mathrm{J}_{\max }$, leaf and air temperatures, air $\mathrm{CO}_{2}$, and relative humidity in a semi-closed greenhouse from June 22 to August 9, 2021.

\begin{tabular}{llccc}
\hline \hline $\begin{array}{c}\text { Dependent } \\
\text { variable }\end{array}$ & Variable entered & $\begin{array}{c}\text { Partial } \\
\text { R-square }\end{array}$ & $\begin{array}{c}\text { Model } \\
\text { R-square }\end{array}$ & Pr $>$ F \\
\hline \multirow{6}{*}{$\mathrm{V}_{\text {cmax }}$} & Leaf temperature & 0.9860 & 0.9860 & $<.0001$ \\
& $\mathrm{~J}_{\max }$ & 0.0123 & 0.9983 & $<.0001$ \\
& Air temperature & 0.0001 & 0.9984 & $<.0001$ \\
& Air $\mathrm{CO}_{2}$ & 0 & 0.9984 & $<.0001$ \\
& Relative humidity & 0 & 0.9984 & $<.0001$ \\
\hline
\end{tabular}

Table 7. Partial R-Square and multiple regression analysis by stepwise between calculated $A_{n}$ (net photosynthesis rate), leaf and air temperatures, $\mathrm{CO}_{2}$ and relative humidity, and calculated leaf respiration in the semi-closed greenhouse during the June 22 to August 9, 2021.

\begin{tabular}{clccc}
\hline $\begin{array}{c}\text { Dependent } \\
\text { Variable }\end{array}$ & \multicolumn{1}{c}{ Variable Entered } & $\begin{array}{c}\text { Partial } \\
\text { R-Square }\end{array}$ & $\begin{array}{c}\text { Model } \\
\text { R-Square }\end{array}$ & Pr $>$ F \\
\hline \multirow{6}{*}{$\mathrm{A}_{\mathrm{n}}$} & Leaf temperature & 0.986 & 0.986 & $<.0001$ \\
& Calculated leaf respiration & 0.011 & 0.997 & $<.0001$ \\
& Air $\mathrm{CO}_{2}$ & 0.000 & 0.997 & $<.0001$ \\
& Relative humidity & 0.000 & 0.997 & $<.0001$ \\
& Air temperature & 0.000 & 0.997 & $<.0001$ \\
\hline
\end{tabular}




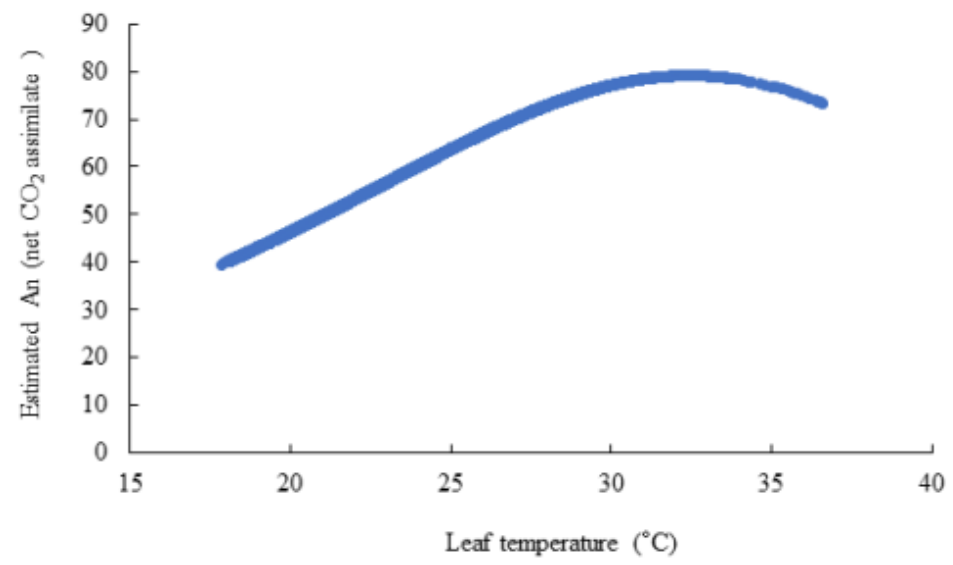

Fig. 3. Estimated net photosynthesis rate $\left(A_{n}\right)$ response to leaf temperature in a semi-closed greenhouse from June 22 to August 7, 2021.

apical region were saturated at a light intensity of 1200 $\mu \mathrm{mol} \cdot \mathrm{m}^{-2} \cdot \mathrm{s}^{-1}$ and reached the saturation point at a $\mathrm{CO}_{2}$ concentration of $1000 \mu \mathrm{mol}$ from June to August. Jung et al. (2015) developed two-variable leaf photosynthetic models of Irwin mango to determine adequate light intensity levels and $\mathrm{CO}_{2}$ concentrations for mango grown in greenhouses. In that study, results showed that photosynthetic rates of top leaves were saturated at a light intensity of $400 \mu \mathrm{mol} \cdot \mathrm{m}^{-2} \cdot \mathrm{s}^{-1}$, while those of middle and bottom leaves saturated at $200 \mu \mathrm{mol} \cdot \mathrm{m}^{-2} \cdot \mathrm{s}^{-1}$, indicating photosynthetic rates can be estimated differently for validation of the model. ScarasciaMugnozza et al. (1996) suggest that the long-term acclimation to high $\mathrm{CO}_{2}$ could result a down-regulation of photosynthesis by reducing rubisco activity, stomatal aperture and density. The present study suggests that optimal conditions of $\mathrm{CO}_{2}$ concentration could be determined for improving photosynthetic rates of fruit vegetables grown in greenhouses by using the photosynthetic model equation.

\section{Acknowledgement}

This study was conducted with the support of the Korea Smart Farm R\&D Foundation (Project no. 421040-04) of Korea Institute of Planning and Evaluation for Technology in Food, Agriculture and Forestry.

\section{Literature Cited}

Bernacchi C.J., E.L. Singsaas, C. Pimentel, A.R. Portis, Jr and S.P. Long 2001, Improved temperature response functions for models of Rubisco-limited photosynthesis. Plant Cell Environ 24:253-259. doi:10.1111/j.1365-3040.2001.00668.x

Caemmerer S.V. 2000, Biochemical Models of Leaf Photosynthesis. CSIRO Publishing, Collingwood, Victoria, Australia. pp 1-165.

Campbell G.S., and JM. Norman 1998, Plants and plant communities. In GS Campbell and JM Norman, ed, Introduction to Environmental Biophysics. Springer, New York, pp 239-241.

Collatz G.J., J.T. Ball, C. Grivet, and J.A. Berry 1991, Physiological and environmental regulation of stomatal conductance, photosynthesis and transpiration-a model that includes a laminar boundary-layer. Agric For Meteorol 54:107-136. doi:10.1016/0168-1923(91)90002-8

Farquhar G.D., S. von Caemmerer, and J.A. Berry 1980, A biochemical model of photosynthetic $\mathrm{CO}_{2}$ assimilation in leaves of $\mathrm{C}_{3}$ species. Planta 149:78-90. doi:10.1007/BF00386231

Harley P.C., R.B. Thomas, J.F. Reynolds, and B.R. Strain 1992, Modelling photosynthesis of cotton grown in elevated $\mathrm{CO}_{2}$. Plant Cell Environ 15:271-282. doi:10.1111/j.13653040.1992.tb00974.x

Hikosaka K., K. Ishikawa, A. Borjigidai, O. Muller, and Y. Onoda 2006, Temperature acclimation of photosynthesis: mechanisms involved in the changes in temperature dependence of photosynthetic rate. J Exp Bot 57:291-302. doi:10. 1093/jxb/erj049

Jung D.H., J.H. Shin, Y.Y. Cho, and J.E. Son 2015, Development of a two-variable spatial leaf photosynthetic model of irwin mango grown in greenhouse. Protected Hort Plant Fac 24:161-166. (in Korean) doi:10.12791/KSBEC.2015. 24.3.161

Kattge J., and W. Knorr W 2007, Temperature acclimation in a biochemical model of photosynthesis: a reanalysis of data from 36 species. Plant Cell Environ 30:1176-1190. doi:10. 1111/j.1365-3040.2007.01690.x

Kim D.E., J.K. Kwon, S.J. Hong, J.W. Lee, and Y.H. Woo 
Comparison of Measured and Calculated Carboxylation Rate, Electron Transfer Rate and Photosynthesis Rate Response to Different ...

2020, The effect of greenhouse climate change by temporary shading at summer on photo respiration, leaf temperature and growth of cucumber. Protected Hort Plant Fac 29:306-312. (in Korean) doi:10.12791/KSBEC.2020.29.3.306

Leuning R. 2002, Temperature dependence of two parameters in a photosynthesis model. Plant Cell Environ 25:1205-1210. doi:10.1046/j.1365-3040.2002.00898.x

Medlyn B.E., D. Loustau, and S. Delzon 2002a, Temperature response of parameters of a biochemically based model of photosynthesis. I. Seasonal changes in mature maritime pine (Pinus pinaster Ait.). Plant Cell Environ 25:1155-1165. doi:10.1046/j.1365-3040.2002.00890.x

Medlyn B.E., E. Dreyer, D. Ellsworth, M. Forstreuter, P.C. Harley, M.U.F. Kirschbaum, X. Le Roux, P. Montpied, J. Strassemeyer, A. Walcroft, K. Wang, and D. Loustau 2002b, Temperature response of parameters of a biochemically based model of photosynthesis. II. A review of experimental data. Plant Cell Environ 25:1167-1179. doi:10.1046/j.13653040.2002.00891.x

Nederhoff E.M. 1987, Dynamic optimization of the $\mathrm{CO}_{2}$ concentration in greenhouses: an experiment with cucumber (Cucumis sativus L.). Acta Hortic 229:341-348. doi:10. 17660/ActaHortic. 1988.229.37

Peet M.M., and D.H. Willits 1987, Greenhouse $\mathrm{CO}_{2}$ enrichment alternatives - effects of increasing concentration or duration of enrichment on cucumber yields. J Amer Soc Hort Sci 112:236-241.

Sage R.F., and D.S. Kubien 2007, The temperature response of $\mathrm{C}_{3}$ and $\mathrm{C}_{4}$ photosynthesis. Plant Cell Environ 30:1086-1106. doi:10.1111/j.1365-3040.2007.01682.x

Sanchez-Guerrero M.C., P. Lorenzo, E. Medrano, N. Castilla, T. Soriano, and A. Baille 2005, Effect of variable $\mathrm{CO}_{2}$ enrichment on greenhouse production in mild winter climates. Agric For Meteorol 132:244-252. doi:10.1016/j.agrformet. 2005.07.014

Scarascia-Mugnozza G., P.D. Angelis, G. Matteucci, R. Valentini 1996, Long-term exposure to elevated $\left[\mathrm{CO}_{2}\right]$ in a natural Quercus ilex L. community: Net photosynthesis and photochemical efficiency of PSII at different levels of water stress. Plant Cell Environ 19:643-654. doi:10.1111/j.13653040.1996.tb00399.x

Sharkey T.D. 1985, Photosynthesis in intact leaves of $\mathrm{C}_{3}$ plants: physics, physiology and rate limitations. Bot Rev 51:53-105. doi:10.1007/BF02861058

Sharkey T.D., C.J. Bernacchi, G.D. Farquhar, and E.L. Singsaas 2007, Fitting photosynthetic carbon dioxide response curves for C3 leaves. Plant Cell Environ 30:1035-1040. doi:10.111 $1 /$ j.1365-3040.2007.01710.x

\title{
반밀폐형 온실 내에서 탄산가스 시비에 따른 광강도와 엽온에 반응한 토마토 잎의 최대 카복실화율, 전자전달율 및 광합성율 실측값과 모델링 방정식에 의한 예측값의 비교
}

\author{
최은영 ${ }^{1} \cdot$ 정영애 $^{2} \cdot$ 안승현 $^{3} \cdot$ 장동철 $^{4} \cdot$ 김대현 $^{5} \cdot$ 이동수 $^{6} \cdot$ 권진경 $^{7} \cdot$ 우영회 $^{8 *}$ \\ ${ }^{1}$ 한국방송통신대학교 농학과 교수, ${ }^{2}$ 한국방송통신대학교 대학원 농생명과학과 대학원생, ${ }^{3}$ 한국방송통신대학교 농학과 학부생, \\ ${ }^{4}$ 강원대학교 원예학과 박사후연구원, ${ }^{5}$ 강원대학교 에너지공학과 교수, ${ }^{6}$ 농촌진흥청 농업과학원 박사후연구원, \\ ${ }^{7}$ 농촌진흥청 농업과학원 연구사, ${ }^{8}$ 한국농수산대학 원예환경시스템학과 교수
}

\begin{abstract}
적 요. 본 연구는 반밀폐형 토마토 재배 온실에서 광합성율 극대화를 위한 적정 탄산가스 시비 농도를 구명하고자 광합성 모델을 이용하여 잎의 최대 카복실화율 $\left(\mathrm{V}_{\mathrm{cmax}}\right)$, 최대 전자전달속도 $\left(\mathrm{J}_{\mathrm{max}}\right)$, 열파괴, 잎 호흡 등을 계산하고 실 제 측정값과 비교하였다. 다양한 광도 $\left(\mathrm{PAR} 200 \mu \mathrm{mol} \cdot \mathrm{m}^{-2} \cdot \mathrm{s}^{-1}\right.$ to $\left.1500 \mu \mathrm{mol} \cdot \mathrm{m}^{-2} \cdot \mathrm{s}^{-1}\right)$ 와 온도 $\left(20^{\circ} \mathrm{C}\right.$ to $\left.35^{\circ} \mathrm{C}\right)$ 조건에서 $\mathrm{CO}_{2}$ 농도에 대한 $\mathrm{A}-\mathrm{C}_{\mathrm{i}}$ curve는 광합성 측정 기기를 사용하여 측정하였고, 모델링 방정식으로 아레니우스 함수값 (Arrhenius function), 순광합성율(net $\mathrm{CO}_{2}$ assimilation, $\mathrm{A}_{\mathrm{n}}$ ), 열파괴(thermal breakdown), $\mathrm{R}_{\mathrm{d}}$ (주간의 잎호흡)를 계산 하였다. 엽온이 $30^{\circ} \mathrm{C}$ 이상으로 상승하였을 때 $\mathrm{J}_{\max }, \mathrm{A}_{\mathrm{n}}$ 및 thermal breakdown 예측치가 모두 감소하였고, 예측 $\mathrm{J}_{\max }$ 의 가장 최고점은 엽온 $30^{\circ} \mathrm{C}$ 였으며 그 이상의 온도에서는 감소하였다. 생장점 아래 5 번째 잎의 광합성율은 PAR 200$400 \mu \mathrm{mol} \cdot \mathrm{m}^{-2} \cdot \mathrm{s}^{-1}$ 수준에서는 $\mathrm{CO}_{2} 600 \mathrm{ppm}, \mathrm{PAR} 600-800 \mu \mathrm{mol} \cdot \mathrm{m}^{-2} \cdot \mathrm{s}^{-1}$ 수준에서는 $\mathrm{CO}_{2} 800 \mathrm{ppm}, \mathrm{PAR} 1000 \mu \mathrm{mol} \cdot \mathrm{m}^{-2} \cdot \mathrm{s}^{-1}$ 수 준에서는 $\mathrm{CO}_{2} 1000 \mathrm{ppm}, \mathrm{PAR} 1200-1500 \mu \mathrm{mol} \cdot \mathrm{m}^{-2} \cdot \mathrm{s}^{-1}$ 수준에서는 $\mathrm{CO}_{2} 1500 \mathrm{ppm}$ 을 공급했을 때 포화점에 도달하 였다. 앞으로 광합성 모델식을 활용하여 과채류 온실 재배 시 광합성을 높일 수 있는 탄산시비 농도를 추정할 수 있 을 것으로 판단된다.
\end{abstract}

추가 주제어: 아레니우스 방정식, 순광합성, 루비스코, 포화점, 열파괴 